Inge Sørgård

Kulturrådet

\title{
Middelalderens nordnorske borganlegg
}

Middelalderborgene i Sør-Norge var i stor grad defensive anlegg, anlagt som militære og administrative baser til forsvar mot indre og ytre fiender på det som tradisjonelt ble oppfattet som norsk territorium (Eriksson 1995:113-152, 161). I løpet av middelalderen ble det imidlertid også etablert to borger i Nord-Norge: Skansen i Tromsø og Vardøhus. I motsetning til i sør ble disse anlagt i et territorium som ikke tradisjonelt ble oppfattet som norsk. Den gamle grensen i nord gikk ifølge den islandske sagateksten Rimbegla ved Malangen, og nordligste norske kirke lå i Lenvik (Figenschow 2011:30). De nordlige delene av det som i dag er Troms, samt hele dagens Finnmark, hørte dermed ikke med i det norske rikskongedømmet (se figur 1). Først på 1200- og 1300-tallet ble også disse territoriene deler av rikskongedømmet. I det følgende vil jeg se nærmere på disse to borganleggene. De sentrale problemstillingene vil for det første være å søke årsaken til at de ble etablert, og dernest hvilken funksjon de hadde.

Når det gjelder Skansen og Vardøhus, er både det arkeologiske og det skriftlige kildematerialet som vi etter hvert skal se nærmere på, noe begrenset. Skansen ble til en viss grad arkeologisk undersøkt i 1973 og flere ganger på 1990-tallet, mens det for Vardøhus’ del er gjort lite ut over de undersøkelser Tromsø museum gjorde på 1950-tallet. Mens Skansen ikke er nevnt i det bevarte skriftlige kildematerialet fra middelalderen, har vi et brev fra 1340 som nevner Vardøhus. Deretter er heller ikke Vardøhus nevnt igjen før på 1490-tallet. Beskrivelser og kartmateriale fra 1500- til 1700-tallet gir imidlertid viktig informasjon om borgen i Vardø. Skriftlige middelalderkilder som sagamateriale, islandske annaler, Novgorod-krønikene og diplommateriale gir også en del informasjon om den samfunnskonteksten anleggene oppstod og virket i, som er grunnleggende for å forstå årsaken til at de ble etablert. På grunn av det mangelfulle kildebelegget om anleggene vil komparative perspektiver bli lagt til grunn for å forsøke å forklare borganleggenes funksjon. Først vil jeg imidlertid redegjøre for den historiske samfunnskonteksten de oppstod og virket i, da dette som nevnt er en forutsetning for å forstå deres rolle i samtiden. 


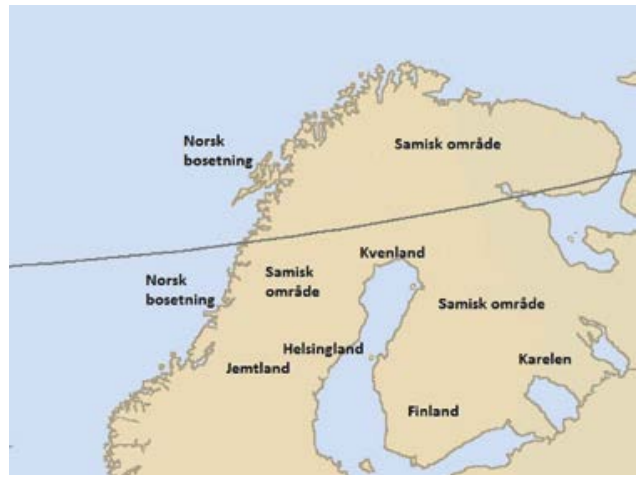

Figur 1. Nordkalotten i tidlig middelalder. Illustrasjon: Inge Sørgård etter Fennoscandia (2016). (C) File:Fennoscandia.png (CC BY-SA 3.0).

\section{Nordkalotten i middelalderen}

Ifølge Egil Skallagrimssons saga var det nordlige Fennoskandia for 1000 år siden bosatt av nordmenn i Hålogaland og Namdalen. Øst for Namdalen lå Jemtland, deretter Helsingland og så Kvenland. Videre østover fikk man Finland og så Karelen. Nord for disse territoriene lå Finnmark, altså samenes territorium (Lie 1970:31). Middelalderens Finnmark omfattet dermed kysten nord og vest for Hålogaland samt hele innlandet på Nordkalotten, inkludert Kolahalvøya (Johnsen 1923:9-11).

Den norske bosetningen i Hålogaland baserte i stor grad sin eksistens på utnyttelse av marine ressurser. I tillegg var jordbruk og gårder viktige som norrøne

identitetsfaktorer (Hansen og Olsen 2004:79). Rimbegla oppgir som nevnt Malangen som norsk grense, men det var spredt norsk bosetning også lenger nord, og det eksisterte egentlig ikke noen fast norsk bosetningsgrense mot de samiske områdene (Nissen 1960:20). Noen samisk bosetningsgrense er det enda vanskeligere å trekke, da vi har spor etter samiske bosetninger i Lofoten og Vesterålen fra både jernalder og middelalder (Hansen og Olsen 2004:79). Det var altså tette forhold mellom den samiske og den norrøne befolkningen.

De håløygske høvdingene i vikingtid og tidlig middelalder baserte en vesentlig del av sin makt på de inntektene de fikk fra innkreving av finnskatt eller handel med samene, samt vekselvis handel og plyndring av områdene rundt Kvitsjøen (Hansen og Olsen 2004:135). Etter hvert som rikskongene fikk kontrollen over Hålogaland, fikk kongemakten også kontrollen med aktiviteten i øst og nord (Hansen og Olsen 2004:153).

Sørøst for Finskebukta ble byen Novgorod grunnlagt senest på 800-tallet, og vokste frem til å bli den viktigste byen nord i det russiske Kiev-riket. Novgorod ble sentrum for et territorium som strakte seg nord til Ladoga, og en viktig handelsby for pelsverk og andre arktiske produkter man fikk fra de enorme områdene østover mot Ural. Som følge av Jaroslav den vises død i 1054 falt Kiev-riket mer eller mindre fra hverandre, og Novgorod oppnådde $i$ de påfølgende årene langt på vei en selvstendig stilling. Bystaten ekspanderte på 1100-tallet nordover, og østkarelerne i nordvest, et folkeslag som Novgorod lenge hadde hatt kontakter med, ble tettere knyttet til bystaten. De karelske høvdingene fikk beholde sin makt lokalt, men måtte betale skatt og bistå Novgorod militært ved behov. Til gjengjeld fikk karelerne tilgang til Novgorods handelsnettverk, og dermed avsetning på pelsverk og andre luksusvarer som via Novgorod ble eksportert til Vest-Europa (Hansen og Olsen 2004:138, 155156).

Karelernes tilknytning til Novgorods handelsnettverk synes å ha ført til at norske handelstokter til Kvitsjøen opphørte, og stimulerte til en utstrakt handel og skattlegging av samene fra karelernes side (Johnsen 1923:19). De konkurrerende interessene førte raskt til åpen konflikt på Nordkalotten (se Tordsson 1979 [1265]:86). Resultatet av det ser vi blant 
annet i Gulatingsloven, som har en bestemmelse om at håløygene skulle utruste en tredvesesse og 13 tyvesesser til leidangsflåten, syv i den søndre delen av Hålogaland og seks i den nordre, da de hadde vaktholdet østover (Robberstad 1937:253). En fredsavtale fra 1251 mellom Håkon Håkonsson på den ene siden, og Novgorod på vegne av karelerne på den andre siden, bekrefter inntrykket av en større konflikt mellom nordmennene og karelerne om retten til finnskatt og handel med den samiske befolkningen (Tordsson 1979 [1265]:266267). Fredstraktaten ble imidlertid etter kort tid brutt da vi hører om angrep østfra på Hålogaland i 1271 i islandske annaler (Storm 1888:138, 331).

I 1279 ble så kong Magnus'sysselmann tilfangetatt på vidda, og 35 av mennene hans ble drept (Storm 1888:70, 141). Rundt 1300 virker det nærmest som nordmennene ble fordrevet fra sin aktivitet i Finnmark, da det gikk flere år uten at kongen fikk finnskatt (Johnsen 1923:20). Studier av engelske tollregnskaper fra 1200- og 1300-tallet har da også vist at pelsimporten fra Norge etter hvert ble fortrengt til fordel for hanseatiske leveranser over Østersjøen (Wallerström 1995:195-196).

Samtidig vokste det frem en stadig større etterspørsel etter tørrfisk ute i det katolske Europa i forbindelse med fastetidene. Det resulterte i en betydelig tørrfiskeksport fra NordNorge, og skattlegging av denne handelen ble etter hvert den viktigste finansielle faktoren i statens utenrikspolitikk (Urbanczyk 1992:230). I lys av dette ser vi en gradvis etablering av fiskevær langs Troms- og Finnmarkskysten på 1200- og 1300-tallet (Lind 2000:47; Bruun 2011). Kongemakten har mest sannsynlig vært en pådriver for denne fiskeribaserte norske bosetningsekspansjonen, som materialiserte seg i Håkon Håkonssons etablering av en kirke i Troms (Tordsson 1979 [1265]:341).

Den norske bosetningsekspansjonen nord- og østover må ha blitt ansett som en trussel mot Novgorods interesser på Nordkalotten, som etter hvert også omfattet Kolahalvøya (Johnsen 1923:19-20; Christiansen 1997:180). På 1200-tallet ekspanderte også Sverige østover, underla seg det som i dag er Sør-Finland, og kom dermed i et konfliktforhold med Novgorod, som så sine handelsruter via Finskebukta truet. Norges union med Sverige i 1319 kan ha ført til at Novgorod anså Norge og Sverige som en og samme fiende. Det virker i hvert fall som konflikten mellom Novgorod og Norge ble trappet opp etter 1319 (Johnsen 1923:24, 30). Angrepene på Hålogaland og mot den norske bosetningen på Finnmarkskysten eskalerte, og i 1323 ble riksforstander Erling Vidkunssons gård på Bjarkøy brent (Storm 1888:346).

En tiårig fredstraktat mellom Novgorod og Norge ble så inngått i 1326 (RN IV, nr 416). Den fastsatte området mellom Lyngstua og den østlige spissen av Kolahalvøya som felles skattland. Vi ser at fredstraktaten fra 1251 ble fremforhandlet av Norge på den ene siden og Novgorod på vegne av østkarelerne på den andre, mens fredstraktaten fra 1326 ble inngått mellom Norge og Novgorod direkte (Johnsen 1923:20, 24).

I 1349 ble imidlertid norske bosetninger i Finnmark og Hålogaland på nytt angrepet østfra (Storm 1888:354). Vi hører så i det bevarte skriftlige kildematerialet om nye angrep i 1386, 1411 og 1444, og motangrep mot områdene rundt Hvitehavet i 1419 og 1445 (Storm 1888:283; Michell og Forbes 1914:189, 203). De mange angrepene østfra har satt spor etter seg i form av såkalte russesagn som synes å ha holdt seg uendret over lang tid, og som er registrert fra slutten av 1600-tallet og fremover (Bratrein 1977). I Troms og Vest-Finnmark finner vi gjerne sagnene i tilknytning til fjordene, og de forteller ofte om angrep som kom over land, mens vi i resten av Finnmark finner dem i tilknytning til fiskeværene, som tyder 
på at angrepene her kom over havet østfra (Bratrein 1977:10-11). Etter 1445 hører vi ikke mer om større angrep i det skriftlige kildematerialet. Bakgrunnen for at konflikten virker å ha ebbet ut rundt midten av 1400-tallet, er vanskelig å fastslå med sikkerhet, men Novgorod ble på denne tiden svekket og i 1478 annektert av storfyrstedømmet Moskva. Norge ble dessuten tettere knyttet til Danmark, som hadde et bedre forhold østover enn Sverige.

Mens trusselen østfra var overhengende, ble det imidlertid iverksatt norske mottiltak. Den nevnte bestemmelsen i Gulatingsloven om at leidangsstyrken i nordre del av Hålogaland hadde vaktholdet østover viser det. En lovtekst fra 1384 nedla forbud mot å seile til Bergen for alle menn i Finnmark og Hålogaland, siden de skulle forsvare landsdelen mot russiske og karelske angrep (Keyser og Munch 1849:222-223; Tveit 2015:141). Fra 1420 har vi dessuten en klage fra Hålogaland og Finnmark til kongen om at man måtte ligge ute i orlog «bathe winter ok sømar» (DN I, nr 670). Ut fra dette synes det som leidangen var et viktig forsvarstiltak gjennom denne urolige perioden.

Det faktum at Bjarkøy ble angrepet, og at mange av de norske bosetningene som ble herjet i Hålogaland og Finnmark må ha vært fiskevær ute på øyer langs kysten, tyder på at angrepene kom over havet i tillegg til over land. Denne antakelsen styrkes av at leidangsflåten også måtte være operativ på sommeren, en årstid da det var utfordrende å forflytte seg over land fra karelske og russiske bosetningsområder i øst til Hålogaland og kysten av Finnmark. Vi ser også at de norske gjengjeldelsesangrepene rammet nettopp kystene langs Kvitsjøen.

Leidangsskipene gjorde forsvarsstyrkene mobile ved at de kunne tilbakelegge betydelige distanser på forholdsvis kort tid, og bruk av leidangsstyrker kan derfor ha vært et relativt effektivt forsvarstiltak mot angrep østfra. Tyvesessene ble i utgangspunktet rodd av 40 menn, men hadde antakelig dobbelt så stor besetning (Ersland 2000:85). Dermed utgjorde leidangsstyrken med de seks tyvesessene i nordre del av Hålogaland 480 mann. I tillegg kommer tredvesessen, som var det største skipet i hele den norske leidangsstyrken og kanskje hadde så mye som 120 manns besetning (Ersland 2000:85). Den samlede teoretiske forsvarsstyrken i nord ble dermed 600 mann. Vi vet imidlertid ikke i hvor stor grad lovverket ble etterlevd med tanke på størrelse og antall leidangsfartøyer, men tallet virker ikke usannsynlig i lys av at det norske angrepet østover i 1419 talte 500 mann (Michell og Forbes 1914:189). Når karelerne og russerne til tross for den norske leidangen flere ganger klarte å ramme norske bosetninger helt ned til Bjarkøy, tyder dette på at leidangen enten ikke var mobilisert, var nedkjempet, eller hadde trukket seg tilbake. I andre tilfeller kan de angripende styrkene ha vært så små og mobile at de klarte å unngå forsvarerne. I tillegg til leidangen må de norske borgene i nord ha vært viktige forsvarsverk.

\section{Skansen i Tromsø}

Skansen i Tromsø er et sirkelformet borganlegg som i dag har en diameter på om lag $50 \mathrm{~m}$, beliggende på østsiden av Tromsøya, like sør for Tromsøbrua (figur 2). Anlegget består av et rundt, kunstig platå om lag 2 m over naturlig bakkenivå. Langs kanten går en opp mot en $1 \mathrm{~m}$ høy voll. I dag ligger anlegget på grunn av landhevingen godt inne på land, men tidligere har det ligget på et nes omgitt av hav i sør, øst og vest (Arntzen 1971:5; Lind 2000:39). Peter Schnitler omtaler i sin grenseeksaminasjonsprotokoll fra 1743 Skansen som rester etter en liten og gammel jordskanse med vollgrav (Nissen 1960:21-22; Arntzen 1971:5). 


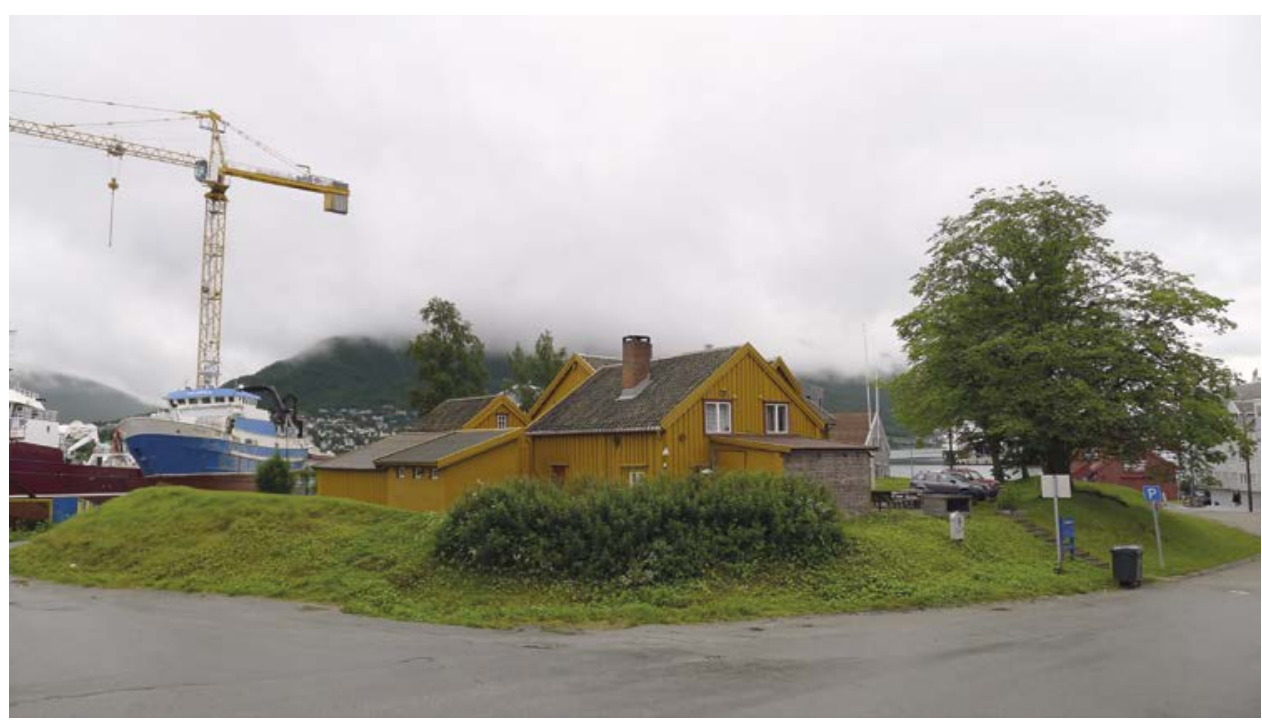

Figur 2. Skansen i Tromsø. Foto: Inge Sørgård.

Schnitler påpeker videre at gamle sagn fortalte at Skansen ble anlagt til forsvar mot russere (Schnitler i Arntzen 1971:5). Geologen Karl Pettersen skrev i en artikkel i Tromsøposten i 1878 at Skansen ennå omkring midten av 1800-tallet hadde en vannfylt vollgrav (Lind 2000:39). Vollgraven er i dag borte, men må tidligere ha skilt borganlegget fra neset i nord. Tilstedeværelsen av vollgrav tyder på at anlegget er fra middelalderen. Vollgraven er antakelig blitt til ved at masse er tatt ut for å bygge opp platået som utgjør selve borgen og vollen rundt dette platået (Lind 2000:43).

En mindre, arkeologisk undersøkelse av Jens Storm Munch i 1973 avdekket at vollen rundt platået hadde et steinfundament i ytterkant (Lind 2000:40). Nye arkeologiske undersøkelser gjennomført av Tromsø museum og Universitetet i Tromsø i 1990, 1991 og 1992 viste at dette fundamentet antakelig går rundt anlegget. Steinfundamenteringens funksjon har sannsynligvis vært å forhindre erosjon (Lind 2000:40-42). En lignende konstruksjon er kjent fra Sarpsborg, der St. Olavs voll fra starten av 1000-tallet hadde steinfundament og vollgrav på utsiden (Fischer 1951:13,26). Antakelig har også Sigurd Jorsalfars Konghelle i Bohuslän og kong Øystein Magnussons virke på Agdenes fra første halvdel av 1100-tallet vært lignende konstruksjoner av stein, jord og tre (Fischer 1951:33-35; Sturlason 1984:248, 250). I Håkon Håkonssons saga får vi vite at også kong Håkon sto bak et forsvarsverk ved Agdenes (Tordsson 1979[1265]:341). Om det her dreier seg om en istandsetting av anlegget fra starten av 1100-tallet, eller om det var et nytt anlegg, vet vi ikke.

Ved undersøkelsen av Skansen i 1990 ble det gjort funn av en pilespiss av jern datert til mellom 900- og 1400-tallet. Det ble også påvist rester etter en mur inne på borgområdet som var om lag $1 \mathrm{~m}$ høy, og som fortsatte inn under Bårstua (Lind 2000:41). Undersøkelsene i 1991 og 1992 viste at denne muren ikke har noen forbindelse med selve vollen som omkranser anlegget (Lind 2000:42). Disse undersøkelsene påviste også vollgraven (Lind 2000:42). Sommeren 1999 ble det foretatt gravearbeider i forbindelse med at Bårstua fra 1700-tallet 
oppe på borgområdet skulle restaureres. Tromsø museum overvåket arbeidet, og det ble samlet inn organisk materiale som ble C14-datert til å være fra perioden mellom midten av 1200-tallet og starten av 1300-tallet (Lind 2000:44). De arkeologiske undersøkelsene gir altså antydninger både om anleggets oppbygging og om datering. Det arkeologiske grunnlaget for datering støttes av Peter Schnitlers opplysninger om et gammelt sagn som forteller at Skansen skal ha vært anlagt til beskyttelse mot russiske angrep (Arntzen 1971:5). Med tanke på det vi vet om konflikten med karelerne, blir da perioden mellom starten av 1200-tallet og midten av 1400-tallet den mest aktuelle, sannsynligvis før Vardøhus ble anlagt i første halvdel av 1300-tallet.

Fra Sverige har vi en interessant parallell i Borgnäs i Västergötland, som er anlagt på et nes med en stein- og jordvoll på landsiden av neset, og antakelig har hatt trepalisader på sjøsidene (Lovén 1999:408). Vi kjenner også fra Sverige til sirkulære vollanlegg anlagt på flatmark som sannsynligvis tidligst er fra 1200-tallet da de har vollgraver, som ikke er kjent på det svenske fastlandet før i dette århundret (Lovén 1999:427-428). Vi kan ikke helt utelukke at disse vollgravene er modifiseringer utført på eldre anlegg, men vollgravene tyder i hvert fall på at stein- og jordbefestninger på flatmark var i bruk i Sverige på 1200-tallet.

Alle disse svenske anleggene betegnes av Christian Lovén som svake borger (Lovén 1999:408, 427-428). Det samme kan sies om Skansen i Tromsø dersom man sammenligner med 1200-tallsborger i Sør-Norge, som for eksempel Valdisholm. Man kan imidlertid ikke sammenligne disse anleggene isolert sett for å avgjøre om de er svake eller sterke anlegg. Man må ta $\mathrm{i}$ betraktning den regionale og lokale samfunnskontekst anleggene opererte innenfor, og da spesielt den trusselen borgene ble bygget for å møte. Da europeerne erobret store deler av det amerikanske kontinentet på 1500-tallet, bygget de forskjellige typer befestninger alt etter hvilken motstand de ventet å møte. Enkle befestninger av tre var ofte tilstrekkelig i innlandet der man kun ventet motstand fra urbefolkningen og ikke andre europeere (Kaufmann og Kaufmann 2004:183). Middelalderborgene på Østlandet og i Bohuslän ble bygget for å sikre disse regionene mot svenske og danske angrep, samt lokale og regionale opprør. Skansen i Tromsø ble bygget for å møte karelske og russiske angrep, og da må vi se Skansen i lys av den trusselen slike angrep representerte.

Henriks krønike fra Baltikum forteller at russerne og deres allierte på starten av 1200-tallet ikke kjente til avansert beleiringsutstyr. Fyrsetting, undergraving eller direkte storming var ifølge krøniken de angrepsmetodene man i stedet benyttet seg av, i tillegg til utsulting (Sagvolden 2003:197). Det er omtrent samme angrepsmetoder som man kunne forvente mot borger i Sør-Norge før borgerkrigene på 1100-tallet, og som St. Olavs voll, Konghelle og kong Øysteins virke på Agdenes ble bygget med tanke på å forsvare seg mot. Først etter de mongolske invasjonene på 1200-tallet tok russerne i bruk moderne beleiringsvåpen, og gikk fra å benytte tre og jord i sine borger til å bygge i stein og tegl (Kaufmann og Kaufmann 2004:35, 121, 126; Nossov 2007:51).

Offensiv krigføring i middelalderen kan grovt sett deles inn i to typer: erobringskriger for å ta eller overta kontrollen over nye landarealer, og plyndringstokter eller raid med det formål å skaffe utbytte og/eller å demoralisere en motstander (Nicholson 2004:2-4). Denne siste type angrep ble ofte gjennomført med små styrker, og søkte å unngå fiendtlige troppekonsentrasjoner eller befestninger, slik vi for eksempel ser i Latvia på 1200-tallet (Nicholson 2004:128; Turnbull 2004:36). De karelske angrepene var av denne siste typen, og i lys av det var altså Skansen tilstrekkelig teknologisk avansert til å møte trusselen østfra, i hvert fall 
til midten av 1200-tallet, og en langt mindre ressurskrevende konstruksjon enn et murt borganlegg.

At Skansen var teknologisk tilstrekkelig, bekreftes også når vi ser på andre samtidige borganlegg i Baltikum og Russland. Den tyske orden, en ridderorden stiftet i 1190, benyttet seg av jord- og treborger i Baltikum så sent som i 1286, da treborgen Heilingberg var sentral i bekjempelsen av semgallerne (Urban 1975:244-245). Landskrona anlagt av svenske styrker i 1300 på en odde mellom Neva og sideelven Ochta i det som i dag er Sankt Petersburg, var også en tre- og jordbefestning beliggende tvers over odden med vollgrav og antakelig flere tårn (Lovén 1999:99-100). Landskrona måtte riktignok anlegges hurtig, og hadde man hatt bedre tid, ville man trolig bygget et mer moderne anlegg i mur, slik som Tavastehus eller Viborg. Tre- og jordbefestningen som ble oppført, motsto likevel et russisk angrep samme år som den ble bygget, før den falt i 1301 (Sundberg 1999:103-104). Man kan ikke se bort fra muligheten for at også Skansen måtte etableres i løpet av kort tid, kanskje på grunn av en overhengende fare for angrep, og at befestningen fikk sin utforming som et resultat av det, i tillegg til at man anså en jord- og trebefestning som fortifikatorisk tilfredsstillende.

Det faller naturlig å sette etableringen av Skansen i forbindelse med kong Håkon Håkonssons offensive politikk i nordområdene. I 1237 avla Håkon Håkonsson et korstogsløfte til paven hvor han lovet å dra på korstog til Det hellige land (Storm 1888:25; Svenungsen 2016:158). Under pave Innocent IIIs regjeringstid, fra 1198 til 1216, hadde man imidlertid åpnet for korstog mot alle kirkens fiender. Dermed ble både den muslimske befolkningen på Den iberiske halvøy, de hedenske folkeslagene rundt Østersjøen og de ortodokse kristne i Russland legitime korstogsmål (Figenschow 2011:29). I 1241 ga dermed pave Gregor IX kongen lov til å frafalle løftet om korstog til Det hellige land, mot i stedet å føre korstog mot sine hedenske naboer (DN I, nr 24). Kanskje var kongens kirke i Troms og etableringen av Skansen resultatet av dette korstoget mot hedningene som vi ikke hører mer om?

Mongolene angrep de østlige russiske statene i 1237, et angrep som førte til at Novgorod var eneste frie russiske stat i 1241. Da den mongolske lederen Ögedei khan døde i desember 1241, trakk mongolene seg året etter tilbake østover. Mongolenes angrep skapte imidlertid et maktvakuum i vest som ble forsøkt utnyttet av Sverige og Den tyske orden, som ekspanderte østover på henholdsvis nord- og sørsiden av Finskebukta (Urban 1975:165-166). Til tross for at Novgorod sto alene og var svekket av de mongolske angrepene østfra, ble først svenskene slått i et slag ved Neva i juli 1240, før Den tyske orden ble slått tilbake i 1242 (Christiansen 1997:117, 134-135). Det er ikke usannsynlig at også Håkon Håkonsson forsøkte å utnytte at karelernes overherrer var svekket, og etablerte Skansen for å få kontrollen over det som i dag er Nord-Troms.

Utfordringen med denne hypotesen er at Håkon Håkonssons saga nokså utførlig nevner alle større byggeprosjekter kongen igangsatte i sin tid, og Skansen er ikke nevnt. At Skansen er utelatt, kan umulig skyldes anleggets relativt sett beskjedne omfang, siden anlegget på Agdenes er nevnt. Vi kan imidlertid ikke se bort fra at den kirken som nevnes i Håkon Håkonssons saga faktisk var lokalisert til nettopp Skansen, altså at kirken lå beskyttet som en del av borganlegget, og at Skansen slik er indirekte nevnt.

I Håkon Håkonssons saga står det kun at kirken er oppført i Troms. I 1246 ga paven Håkon Håkonsson patronatsrett over de kirkene han skulle anlegge nær «hedningene», og i 1308 er kirken oppgitt som et av landets 14 kongelige kapeller (DN I, nr 37; DN I, nr 113). 
En kirke oppført av kongemakten ville utgjort et opplagt mål for en fiende, og plyndring eller ødeleggelse av kirken må ha fremstått som et betydelig nederlag for kongen og underminert den manifestasjonen på Håkon Håkonssons makt som hans kirke i nord utgjorde. Til tross for kildenes mange nedtegnelser om angrep østfra finner vi ingen vitnesbyrd om at det kanskje viktigste symbolet på norsk overhøyhet, kongens kirke i Troms, ble rammet. Teksten på et kart fra 1788 over Tromsøyas østre kystlinje omtaler en bygning som skal ha stått på Skansen før reformasjonen (Lind 2000:39). Den tidligere omtalte muren inne på borgplatået kan være fundamentene til denne bygningen. Det er ikke umulig at den omtalte bygningen er rester etter kongens kirke. Det var sterke bånd mellom de kongelige kapellene og kongemakten. To av kapellene lå ved kongsgårdene i Oslo og Bergen, og tre på de eldre kongsgårdene i Egersund, Avaldsnes og Lista (Trædal 2008:157). Mikaelskirken, et av de kongelige kapellene i Tønsberg, inngikk dessuten som en del av Tunsberghus.

Befestede kirker er kjent fra store deler av den kristne verden, og forekommer spesielt $\mathrm{i}$ kristendommens randsoner eller på grensene mellom forskjellige retninger innen kristendommen (Harrison 2004). Et særlig interessant eksempel er Korois, øst for Åbo, i Finland (se figur 3). Her ble det antakelig på 1200-tallet anlagt en kirke på et nes i elven Aura, avskåret fra land med vollgrav og voll. Inne på det befestede området finner man i dag i tillegg til kirkeruinen også rester etter to andre steinbygninger (Lovén 1999:263-264). Mellom ca. 1230 og 1290 var Korois domkirke for Åbo stift, og dermed et av de fremste symbolene på svensk overhøyhet i denne delen av Finland. Det er sannsynligvis i den forbindelse at vollgraven og vollen ble anlagt. Korois fremstår dermed både som en fysisk og symbolsk manifestasjon av svensk kontroll og overhøyhet, som en direkte og nærmest samtidig parallell til Skansen i Tromsø. Et sannsynlig tidsrom for etableringen av kirke og borganlegg i Tromsø er mellom 1241, da kongen fikk fritak fra sitt korstogsløfte for i stedet å føre korstog mot «hedningene» i nord, og 1251, da fredsavtalen med Novgorod ble inngått.

\section{Vardøhus}

Det eldste Vardøhus er i dag forsvunnet, men det er hittil antatt at man fra begynnelsen av 1300-tallet har hatt en borg anlagt enten ved Østvågen eller ved Bussesundet, som så i senmiddelalderen ble erstattet av en ny borg i Østvågen. Den var da i bruk frem til dagens stjerneformede anlegg ble etablert på 1700-tallet. Funksjonen til disse to første anleggene har både vært av militær art og, ikke minst, av symbolsk betydning som en markør for det norske rikskongedømmet mot øst (Eriksson 1995:155; Henriksen 2016:424). Første skriftlige kilde vi har som omtaler Vardøhus, er et brev fra februar 1340 fra biskop Håkon i Bergen til Erling Vidkunnsson av Bjarkøy, hvor det nevnes arbeider på Vardøhus som var pålagt erkebispen av kongen: «umbott Tunsbergs huss ok Varghæya» (DN VIII, nr 125). Deretter nevnes ikke borgen i det bevarte skriftlige kildematerialet før utpå 1490-tallet (Nissen 1960:25).

Holger Sinding-Larsen finner det sannsynlig at det eldste Vardøhus ble anlagt i Håkon Vs regjeringstid fra 1299 til 1319 (Sinding-Larsen 1937:4). Denne eldste borgen ble lenge antatt å ha ligget ved Østvågen, på samme sted som det andre anlegget fra rundt 1500 (Sinding-Larsen 1937:6-8). Sinding-Larsen mente imidlertid at gamle kart fra 1726 og 1727 viser levninger etter en eldre befestning ved Bussesundet, tvers overfor Tyvholmen, og pekte på at kartet fra 1727 også har nedtegnelsen «Har staaet et gamelt Slodt» ved 


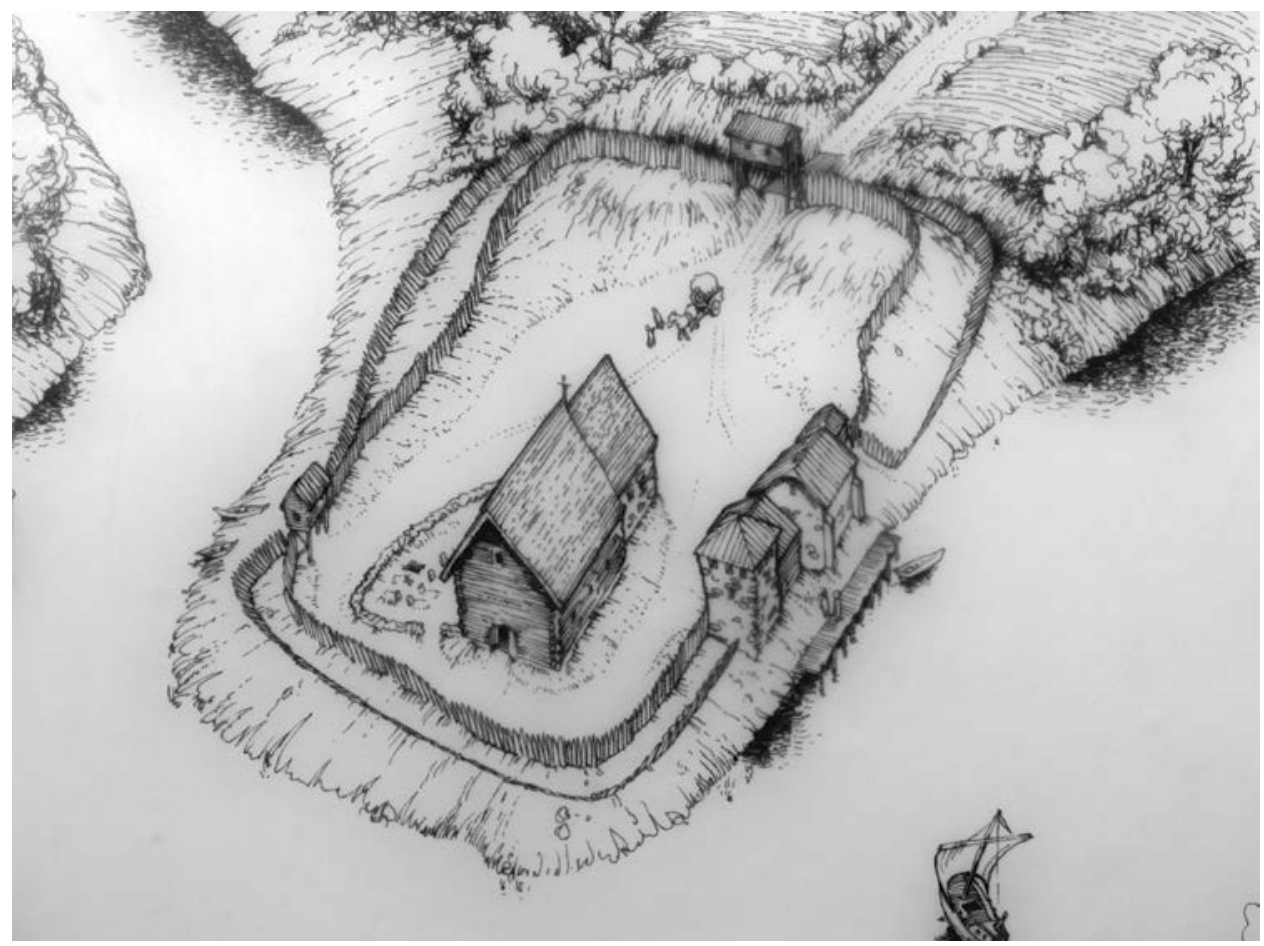

Figur 3. Kirkestedet Korois ved Ảbo i Finland, slik man tror det har artet seg i middelalderen. Foto av skilt ved ruinene etter kirken, Museovirasto. Foto: Inge Sørgård.

Bussesundet (Sinding-Larsen 1937:30-31). Ved en befaring i 1934 fant han her også en $12 \mathrm{~m}$ høy knaus og langs knausens østside noe som minnet om en murflukt, samt en fordypning som han mente kunne være restene etter en vollgrav (Sinding-Larsen 1937:21-24). På bakgrunn av det hevdet Sinding-Larsen at dette måtte være det eldste Vardøhus.

Arkeologiske undersøkelser gjennomført av Tromsø museum i 1954 og 1955 avviste imidlertid Sinding-Larsens hypotese om en befestning ved Bussesundet. Murflukten viste seg å være et naturfenomen, og det ble ikke funnet kulturlag som tyder på menneskelig tilstedeværelse over tid (Simonsen 1959:20-21). Man mente videre at stedets navn ikke hentyder til et gammelt slott, men gammelslotten, altså en slåtteeng (Simonsen 1959:20). Et kart av Michael Jansen Sundt fra 1731 har på samme sted ved Bussesundet som de noe eldre kartene nedtegnelsen «En plads hvor tilforne har været slaget græs og deraf hafver det naufn Gammel Slaat» (Nissen 1960:60-61).

Mens vi helt mangler beskrivelser av denne første borgen, som etter avvisningen av Sinding-Larsens hypotese om Bussesundet må ha ligget ved Østvågen, er det bevart en rekke kart og beskrivelser fra slutten av 1500-tallet og utover av det som er betegnet som den andre borgen i Vardø. ${ }^{1}$ Jan Huygen van Linschotens kart fra 1594 er det eldste bevarte kartet over Vardøhus, og viser en nær kvadratisk ringmursborg beliggende på den østre siden av Østervågen, ikke langt fra kirken (se figur 4). Van Linschotens kart går imidlertid 


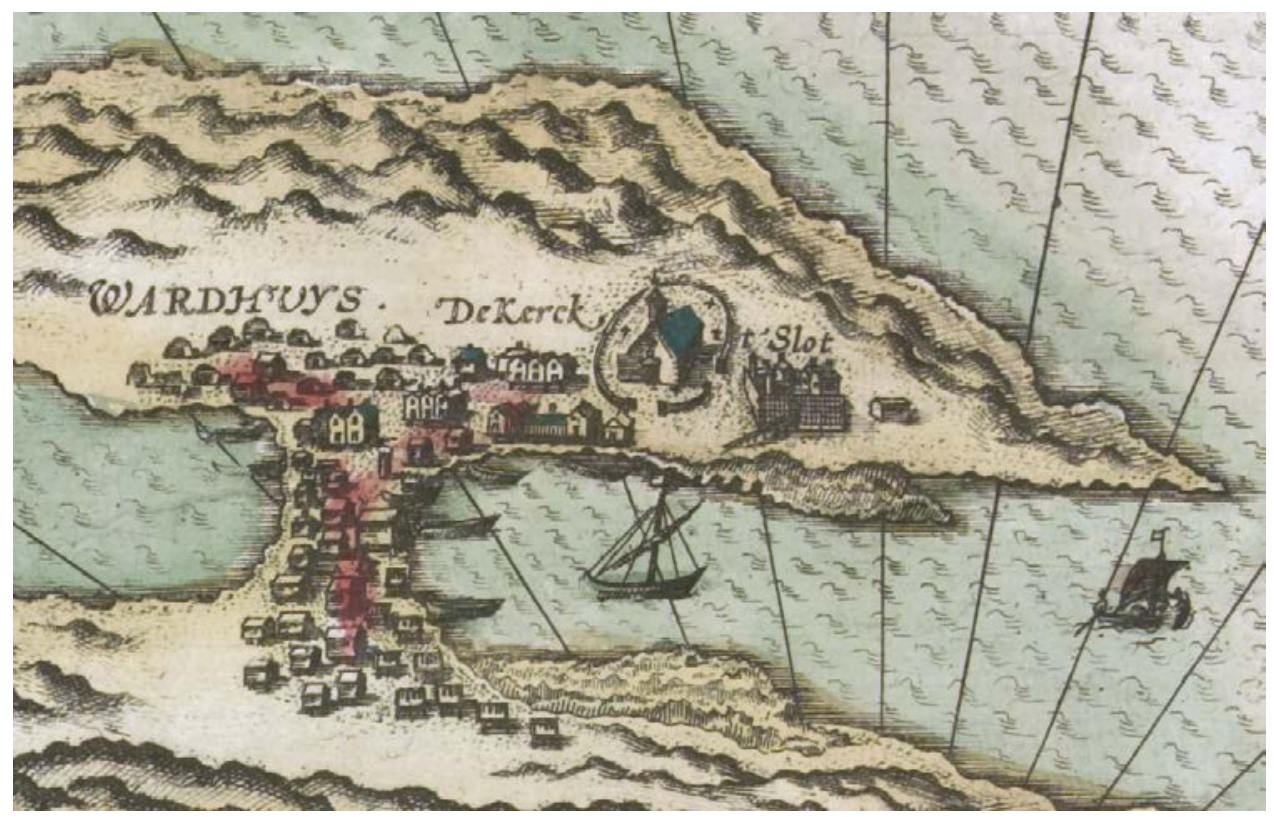

Figur 4. J.H. van Linschotens Vardøkart fra 1594. Nasjonalbibliotekets kartsamling.

ikke i særlig detalj når det kommer til borgens utforming. Van Linschoten beretter for øvrig fra sitt besøk i 1594 at borgen ikke var særlig sterkt befestet, oppført i naturstein med tinder og brystvern av tre som var halvveis forfalne og neppe kunne holde stand mot et velutrustet skip (Nissen 1960:41).

I 1599 gjennomførte kong Christian IV et tokt til Murmanskkysten i Nord-Russland. Fra dette toktet foreligger det to reiseskildringer av henholdsvis Jonas Carisius og Sivert Grubbe, og begge bekrefter inntrykket av Vardøhus som svært forfallen og et anlegg som umulig kunne klare seg i kamp. Det berettes om ringmuren at den var bygget av skiferstein uten kalkbruk og dekket med jord. Dette utgjorde vollen, og på den sto fire jernkanoner. Innenfor ringmuren fantes seks små hus bygget i tømmer (Hagen og Sparboe 2004). Den første noe mer detaljerte tegning av Vardøhus făr vi i 1711 med Isaac Olsens plantegning (se figur 5). På denne tegningen har Vardøhus to diagonalt anlagte rektangulære bastioner. Det samme ser vi av Michael Jansen Sundts beskrivelser (Nissen 1960:54, 60, 62).

Ikke langt fra det sted hvor de nevnte kartene viser Vardøhus plassert, ble det i 1955 funnet flere kanondeler som dateres til rundt år 1500, og i 1958 ble det også funnet en armbrøstbolt (Simonsen 1959:24; Willoch 1960a:167). Selve tomten hvor borgen er avbildet, ble arkeologisk undersøkt i 1955 og 1958 av Tromsø museum. Allerede i 1946 ble rester etter to parallelle øst-vest-gående murer påvist i forbindelse med etablering av nytt vann- og kloakknett i Kristian 4.s gate. Det ble antatt at den søndre muren var rester etter borgens søndre ringmur, mens den nordre var rester etter en grunnmur inne i borggården. Lenger mot nordvest fant man en tredje nordøst-sørvest-orientert mur som ble antatt å være ganske nær borgens nordvestre hjørne. Ut fra murfunnene i sør og nordvest ble en borggård på 


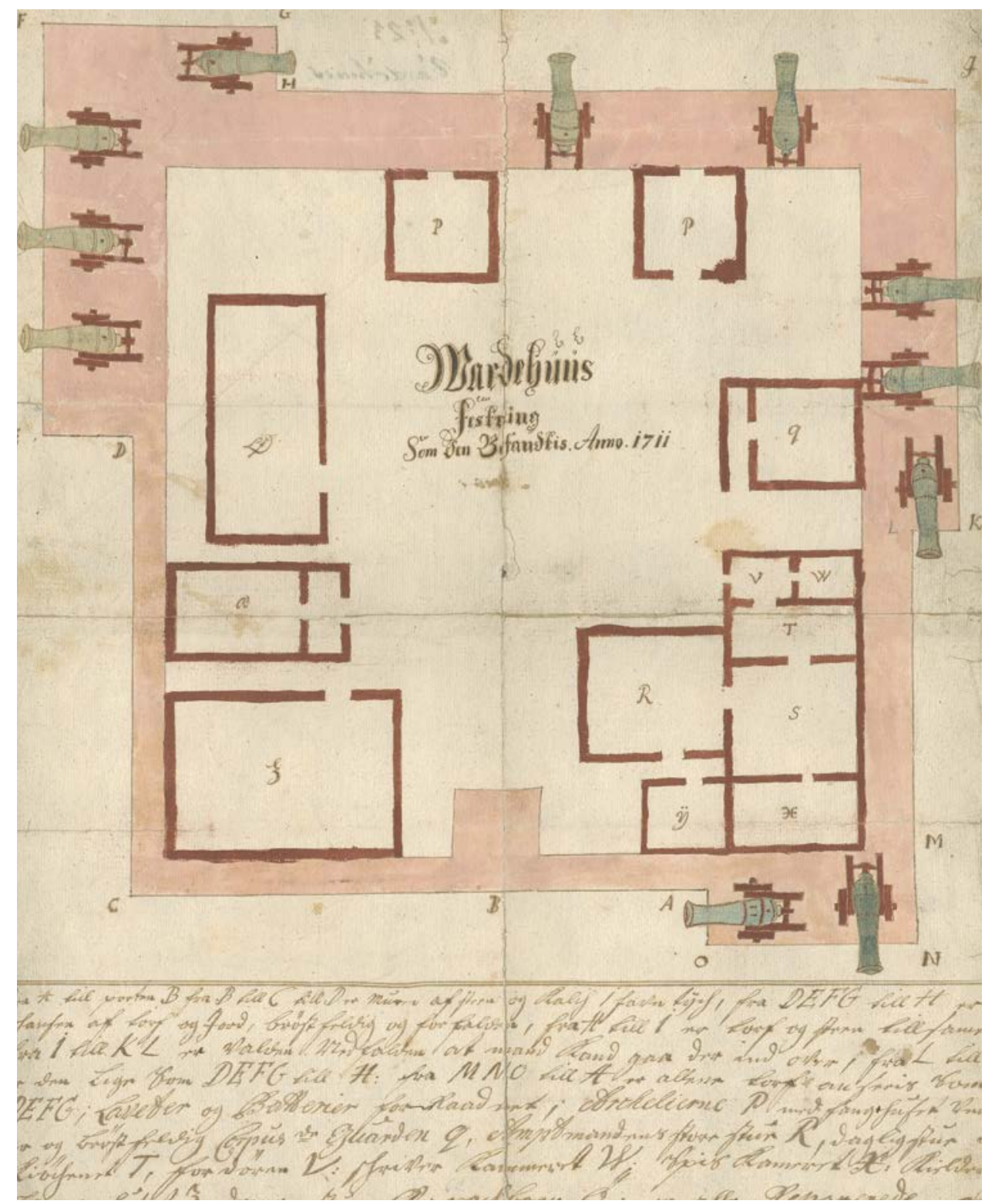

Figur 5. Plantegning av Vardøhus fra 1711, antakelig av Isaac Olsen. Riksantikvarens tegningsarkiv RA 93-0681.

35-40 m fra nord til sør og minst $30 \mathrm{~m}$ fra øst til vest definert (Simonsen 1959:25). Dessverre ble det ikke tatt vare på noen funn fra denne gravingen. De arkeologiske undersøkelsene i 1955 og 1958 gikk ikke lenger ned i bakken enn at de kulturlag og det gjenstandsmateriale som ble funnet, ble datert til 1600-tallet og fremover (Simonsen 1959:27-28). Også ved gravingen i 1955 fant man murrester, nå inne i borggården, og kalkbruk ble påvist i murrestene. Det er ikke opplyst om det ble funnet rester av kalkbruk i 1946. 
Det er ikke ut fra disse undersøkelsene mulig å påvise to befestninger på stedet. I det hele tatt er hypotesen om at det har vært to befestninger i Vardø før dagens stjerneformede anlegg, lite begrunnet. Argumentasjonen for at det Vardøhus vi kjenner fra beskrivelser og kartmateriale fra 1500-tallets slutt og utover er anlagt i senmiddelalderen, bygger på at hjørnetårnene er anlagt for flankerende ild med kanoner, og at betegnelsen slott er tatt i bruk (Sinding-Larsen 1937:12; Simonsen 1959:19, 24). Betegnelsen slott er imidlertid også benyttet om Bergenhus på 1500-tallet (DN XXI, nr 792), og det til tross for at Bergenhus for en stor del ble bygget i siste halvdel av 1200-tallet (Eriksson 1995:145).

Flankerende beskytning fra tårn i ringmurer er dessuten et prinsipp kjent fra antikken, og benyttet i Norden fra 1200-tallet av (Bradbury 1992:3-5; Eriksson 1995:156-157). Det er også et spørsmål om ikke disse bastionene er etterreformatoriske byggverk. Det er først på kart og tegninger fra midten av 1600-tallet vi ser disse bastionene. Tidligere kart, som det nevnte Jan Huygen van Linschotens kart fra 1594, viser borgen uten bastioner, kun med en firkantet ringmur. Bastionene kan dermed ha kommet som en følge av kong Christian IVs besøk i 1599, og den opprustningen som skjedde med Vardøhus på starten av 1600-tallet (Hagen og Sparboe 2004:12). De kan da ha erstattet den vollen som ifølge beskrivelsene fra 1599 fungerte som kanonfundamenter, og som godt kan ha vært anlagt på innsiden av ringmuren.

Gunnar Isaachsen Willoch påpeker dessuten at plasseringen ved Østvågen var lite fordelaktig etter at kanoner kom i bruk på 1400- og 1500-tallet. Østvågen beherskes av høydene innover Vårberget, og Bussesundet som var i bruk som oppankringssted, kunne med den tidens skyts ikke nås fra borgen (Willoch 1960b:66). Den eneste fordelen med plassering av borgen i Østvågen var ifølge Willoch den godt skjermede havnen. Ut fra det skulle man tro at en befestning anlagt sent på 1400-tallet eller på 1500-tallet ville blitt anlagt ved Bussesundet.

I tillegg er borgen ut fra det vi får opplyst gjennom kartmateriale, plantegninger og beskrivelser, morfologisk mer lik en høymiddelalder- eller tidlig senmiddelalderborg enn en borg fra siste del av 1400- eller 1500-tallet. Niels Knag gir i 1694 en beskrivelse av Vardøhus. Befestningen hadde da en østmur på 39,5 m lengde, 4,4 m høyde og 2,2 $\mathrm{m}$ bredde. Vestre side, som lå ut mot Sørvågen, var like lang og bred som østre side, men var bare 3,7 m høy. Porten her var 2,2 m høy og 1,3 m bred. Søndre og nordre mur var 30,2 m lange, 3,9 m høye og 2,2 m brede (se Willoch 1960b:66-67). Fotavtrykket som beskrives her, bekreftes også av de arkeologiske undersøkelsene omtalt tidligere. Altså en rektangulær befestning med et innvendig areal på i overkant av $900 \mathrm{~m}^{2}$ og med 4 m høye og $2 \mathrm{~m}$ brede murer. Det oppgis ikke om murene var bredere nede enn ved murkronen.

Disse smale murene har generelt lite til felles med de borganleggene som ble bygget rundt 1500. De hadde bredere murer, for eksempel om lag $4 \mathrm{~m}$ brede på Steinvikholmen i Trondheimsfjorden, bygget i perioden fra 1525 til 1530 (Nordeide 2000:10). Utviklingen av kanoner var kommet så langt i siste halvdel av 1400-tallet at de kunne benyttes defensivt i forsvaret av befestninger. Borger fra denne perioden er derfor ofte bygget med større rondeller, hvor murene like mye forbinder rondellene som rondellene forsterker murene (Kaufmann og Kaufmann 2004:175-183). Disse rondellene, som vi for eksempel finner på nevnte Steinvikholmen, samt på Olavinlinna i Savonlinna i Finland anlagt i 1475, utgjorde plattformer for eget artilleri, samtidig som de motsto treff fra fiendtlig artilleri bedre enn firkantede tårn (se figur 6). På van Linschotens kart fra 1594 ser vi som nevnt ikke slike rondeller eller andre former for flankerende tårn. 


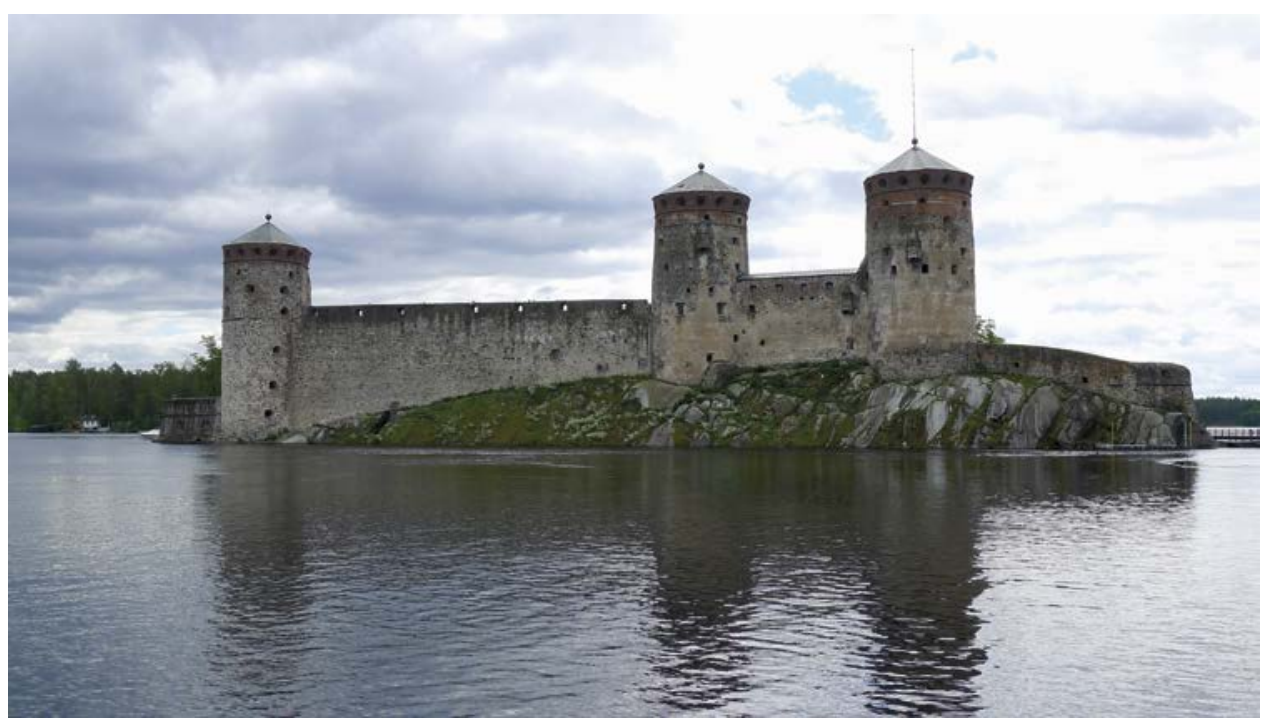

Figur 6. Olofsborg fra slutten av 1400-tallet med sine rondeller benyttet som kanonplattformer. Foto: Inge Sørgård.

Det Vardøhus som beskrives på kart og tegninger fra 1500-tallet og utover, har i stedet flere likhetstrekk med borger fra slutten av 1200-tallet, som de eldste byggetrinnene på borgen i Åbo fra 1280-tallet. Murene var her riktignok $8 \mathrm{~m}$ høye og bredere enn på Vardøhus, men borgen i Åbo ble også opprinnelig bygget som en rektangulær ringmursborg (Lovén 1999:91). Fra starten av har borgen bare hatt ett tårn plassert i vestmuren med hovedinngang og forholdsvis svakt befestede inngangspartier i murene mot øst, nord og sør (Lovén 1999:91-92). Med sine fire inngangsporter har man kunnet forflytte et større antall mennesker eller materiell raskt inn og ut av borgen, og det har gjort at den er blitt betegnet som et forlegningskastell i forbindelse med at svenskene konsoliderte sin stilling som makthavere $i$ det sørvestre Finland (Lovén 1999:92). En annen interessant borg i denne sammenheng er Tavastehus i det sentrale Finland (se figur 7). Det hersker en del usikkerhet rundt tidspunktet for anleggelsen av Tavastehus, men mest sannsynlig er de første byggetrinnene fra slutten av 1200-tallet (Lovén 1999:95-96). Tavastehus var i utgangspunktet bygget som en tilnærmet kvadratisk ringmursborg i naturstein, med om lag $7 \mathrm{~m}$ høye og $33 \mathrm{~m}$ lange murer med skytterganger på toppen (Härö 1981:9). Tavastehus hadde i sin eldste periode antakelig flere trebygninger innenfor ringmuren og tårn bygget i stein i tre av hjørnene (Lovén 1999:94-95). Tavastehus er ikke bare jevnstor med det Vardøhus som beskrives av Niels Knal i 1694, men har også morfologiske likhetstrekk. Det samme gjelder borgen i Åbo.

Som vi har sett for Skansen i Tromsø, er det utfordrende med typologiske dateringer av borger, da utformingen ofte har like stor sammenheng med den trusselen de sto overfor, og den situasjonen man sto i da de ble konstruert, som hvilke arkitektoniske særtrekk som var mest gjeldende i de landene Norge i middelalderen hadde nærmest kontakt med. Jordvoller er da også et trekk som vi ser over lang tid. I middelalderen ble vollanlegg ofte benyttet fordi de var enkle og raske å bygge, og ikke trengte den samme grad av spesialkunnskap som 


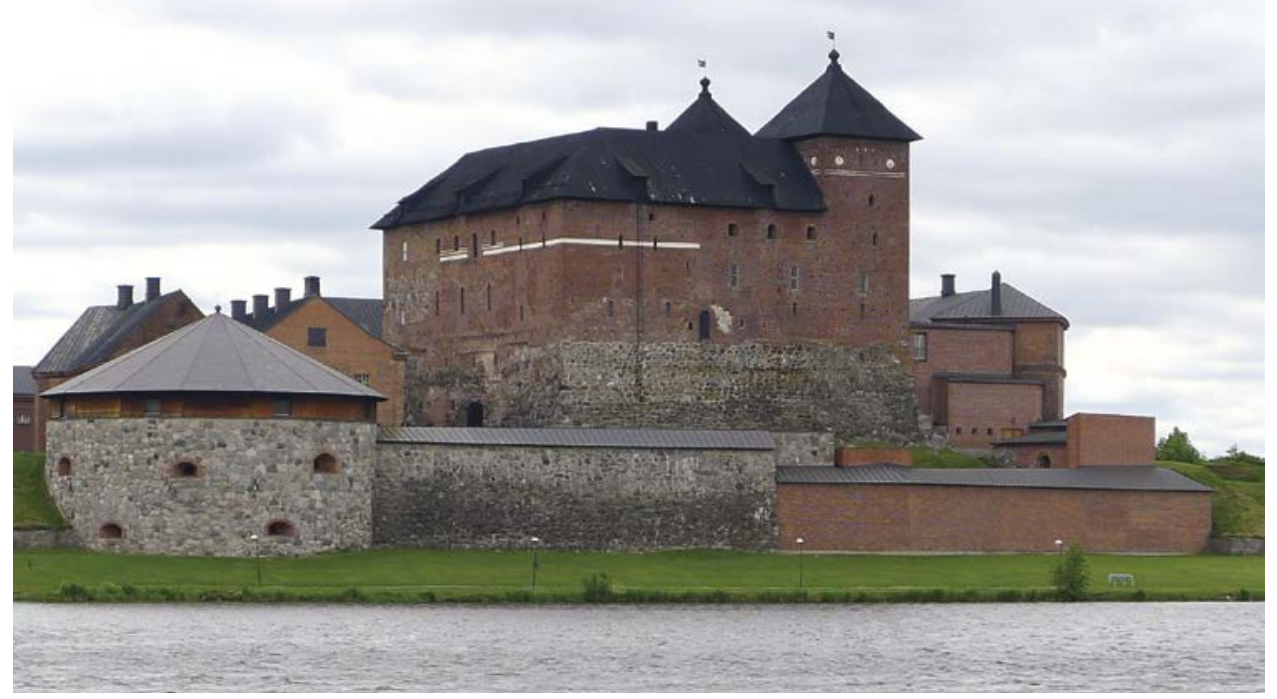

Figur 7. Tavastehus. Den eldste delen av borgen sees sentralt i bildet. Foto: Inge Sørgård.

murte borger. Etter at kanoner ble tatt i bruk, ble vollanlegg i form av skanser fortsatt benyttet, nå fordi vollene absorberte energien fra kanonkuler. Tidlig på 1600-tallet ble Altehus på Årøya i Altafjorden anlagt. Det var et blokkhus i tre omgitt av en sirkelformet voll ikke ulik konstruksjonen i Tromsø (Nissen 1960:25). Altehus er et godt eksempel på at bruk av jordvoller ikke forsvant ved overgangen til kanonartilleri, men fikk en annen funksjon. Borger med relativt høye og tynne murer har vi derimot ikke etter at kanoner ble tatt $\mathrm{i}$ bruk, og i Vardø har vi som nevnt kanonfunn allerede fra rundt år 1500. Vi vet forøvrig at russerne hadde tatt $\mathrm{i}$ bruk kanoner på 1400-tallet (Nossov 2007:52). Legger man i tillegg til grunn beskrivelsene fra slutten av 1500-tallet av Vardøhus som en svak befestning og den lite fordelaktige plasseringen av borgen etter at kanonskyts ble tatt i bruk, tilsier det at borgen er eldre enn fra slutten av middelalderen.

Det er også noe påfallende at til tross for at det skriftlige kildetilfanget generelt øker betydelig i senmiddelalderen, hører vi ikke noe om etablering av en ny befestning i Vardø. Interessant i denne sammenheng er erkebiskop Erik Valkendorfs beretning til paven fra hans besøk til Finnmark i 1512. Her beretter Valkendorf at han var den eneste av erkebiskopene som han visste om som hadde våget å reise så langt som til borgen Vardøhus: «castro Wardehwss» (Karlsson og Storm 1901:6-7). Dette må tolkes dit hen at den borgen Valkendorf besøkte, var av vesentlig alder ved hans besøk siden hans forgjengere hadde hatt mulighet til å besøke den men ikke gjort det. Det er også vanskelig å tro at borgen i Vardø som går igjen i kartmaterialet fra slutten av 1500-tallet og utover, ble anlagt etter Valkendorfs besøk. I den utfordrende politiske situasjonen Norge var i på 1510-, 1520- og 1530-tallet, er det vanskelig å se hvem som skulle prioritert ressurser til oppføring av en ny borg i Vardø, spesielt i lys av at forholdet til Russland forbedret seg i slutten av middelalderen, og kon- 
fliktnivået i nord sank. Valkendorf omtaler da også fiendtligheter med russerne som noe som hadde foregått tidligere (Karlsson og Storm 1901:13). Videre er det litt vanskelig å forstå at en borg bygget på 1540-tallet eller senere, skulle være så dårlig og utdatert på 1590-tallet som van Linschoten, Carisius og Grubbe hevdet. Konklusjonen må bli at det Vardøhus som går igjen i tegninger og kartmateriale fra 1500- og 1600-tallet, og som lå i Østervågen, må være den eneste forløperen til dagens stjerneformede anlegg. Vi har ingen spor som tyder på en tredje, eldre befestning per i dag, etter avvisningen av hypotesen om en eldre borg ved Bussesundet.

Tradisjonelt har man som nevnt antatt at det eldste Vardøhus ble anlagt i løpet av de første tiårene av 1300-tallet, helst det aller første (se for eksempel Sinding-Larsen 1937:3-4; Ekroll 2004). Dette er begrunnet ut fra at det som antas å være den første kirken på stedet, ble innviet i 1307 (Storm 1888:74; Stangeland og Valebrokk 2001:195; Henriksen 2016:393). Byggingen av Vardøhus er som nevnt blitt satt i forbindelse med kong Håkon V, som regjerte frem til 1319 og var den siste norske kongen som bygde borger i stor stil.

En alternativ hypotese er imidlertid blitt fremsatt av Håvard Dahl Bratrein (2002). Som et svar på kong Magnus Erikssons bønn om hjelp mot karelske og russiske angrep på Norge tillot paven i 1326 at halvparten av seksårstienden fra Norge og Sverige, som opprinnelig skulle gå til korstog i Middelhavsområdet, kunne brukes til forsvaret av Norge (DN IV, nr 444; RN IV, nr 261; RN IV, nr 426). Pengene ble kvittert ut i august 1328, altså to år etter at det ble inngått fredsavtale mellom Norge og Novgorod, og skulle forvaltes av den norske erkebiskopen (DN IV, nr 182; RN IV, nr 612). Etter at fredstraktaten ble inngått, er det vanskelig å tro at midlene gikk til en korstogslignende straffe- eller erobringsekspedisjon østover mot Kolahalvøya eller Kvitsjøen, og Bratrein anser det derfor som sannsynlig at midlene ble anvendt til etableringen av Vardøhus. Legger vi dette til grunn, kan de arbeidene erkebiskopen ble pålagt i 1340, like godt være ferdigstillelsen av befestningen som reparasjoner.

Skal Vardøhus ha vært bygget i løpet av de to første tiårene av 1300-tallet, virker det dessuten merkelig at man fra norsk side gikk med på at hele området mellom Lyngstua og den østre spissen av Kolahalvøya skulle være felles skattland med fredstraktaten av 1326. Vardøhus markerte norsk suverenitet over Finnmarkskysten, og derfra har man i stor grad hatt anledning til å kontrollere og å begrense russisk aktivitet i det vestre Finnmark, og dermed et godt forhandlingskort. At man godtok felles beskatning mellom Vardø og Lyngstua, virker dermed som en unødvendig stor innrømmelse om man hadde hatt en relativt ny operativ befestning i Vardø i 1326.

\section{De nordnorske middelalderborgenes funksjoner}

Med tanke på det sparsommelige skriftlige kildematerialet og de få arkeologiske undersøkelsene som er gjort omkring de nordnorske borganleggene, er det vanskelig å si noe sikkert om disse anleggenes funksjon. Noen betraktninger kan man likevel gjøre seg. I middelalderen spilte borganlegg en sentral rolle i kontrollen over territorier. Med utgangspunkt i borganlegg som beskyttede baser kunne kavaleri og infanteri kontrollere de omliggende landområdene (Keegan 1994:139-140; Ersland og Sandvik 1999:20; Nicholson 2004:66, 73). Et nærliggende eksempel er de svenske etableringene av Åbo, Tavastehus, Viborg og Landskrona fra 1200-tallet og starten av 1300-tallet. Gjennom disse borganleggene fikk Sverige kontrollen over det vestlige og sentrale Finland, samt elvene Vuoksa og Neva, og 
dermed handelsveiene mellom Ladoga og Finskebukta. Det førte til at Novgorod måtte gjennomføre mottiltak, og Landskrona ble stormet etter bare ett år, og deretter destruert da man anså denne borgen som en så stor trussel mot Novgorods handel at man ikke våget å la den bestå.

Borganlegg kunne også benyttes som forsvar mot plyndringstokter. På 300-tallet etablerte romerne en rekke befestninger på kysten av Sør-England som ble benyttet som baser for egne styrker med oppgave å slå tilbake germanske plyndringstokter, og frankerne benyttet samme strategi mot vikingene på 800-tallet (Nicholson 2004:73, 75). Sverdbrødrene og Den tyske orden gjorde noe lignende på 1200-tallet gjennom etableringen av en linje med befestninger langs elven Daugava, som den gang utgjorde sydgrensen for det kristne Latvia (Urban 1975:70; Turnbull 2004:11, 36-37). Med utgangspunkt i disse borganleggene patruljerte man omlandet og kunne gi varsel om angrep. Samtidig kunne man trekke seg tilbake til borgene om fienden var overlegen, samle en milits og så avskjære fienden når denne trakk seg tilbake. Konstruksjonen av befestninger og beleiringen av dem ble dermed sentrale elementer i middelalderens krigføring, og det er i lys av dette vi må forsøke å forklare funksjonen til Skansen i Tromsø og Vardøhus.

Det fremgår av klagebrevet fra 1420 at leidangsflåten i nord til tider var nærmest kontinuerlig mobilisert, og den må dermed ha hatt en eller flere baser som den opererte fra. Få lokaliteter kan ha hatt kapasitet til å vedlikeholde og oppbevare forsyninger til den operative leidangsflåten for nordre del av Hålogaland, til tider kanskje på så mange som seks tyvesesser og en tredvesesse. Mangeromstuftene vi finner mellom Lyngenfjorden og Varanger, som dateres til mellom 1200 og 1600, kan tolkes som slike baser for leidangsflåten (Amundsen mfl. 2003:90). Dette er tuftekomplekser der flere tufter eller rom ligger samlet i en klynge. Inngangen til de enkelte rommene går via en felles korridor, og tuftene har kraftige veggvoller. Disse anleggene ligger ved gode havner langs leia, og gir inntrykk av å være befestede boliger for en større mengde mennesker. Vi mangler imidlertid nesten helt funn av våpen som pilespisser eller spydspisser knyttet til mangeromstuftene, til tross for at flere av disse tuftene er grundig undersøkt. Dette gjør det lite sannsynlig at tuftene kan ha vært baser for en leidangsstyrke (Amundsen mfl. 2003:90; Henriksen mfl. 2011:193; Henriksen 2016:449, 453).

Det alternativet som da peker seg ut, er at leidangsflåten hadde baser ved befestningene Skansen og Vardøhus. Bruk av borger som base for leidangsstyrker er kjent fra de sørskandinaviske konfliktene på 1200-tallet, hvor Tønsberghus og borgene langs Øresund fungerte som baser for maritime angrep på Danmark (Fischer 1951:242-243, 262; Eriksson 1995:157; Ersland 2000:100). Povl Simonsen (1959:53) har da også foreslått at Vardøhus kan ha tjent til forsvar for skipsbesetninger og deres skip, slik at de kunne avskjære retrettog forsyningslinjene til en fiende som dro sjøveien vestover. En fiende som kom sjøveien østfra, må ha passert Vardø enten gjennom Bussesundet eller på utsiden av Vardøya, og kunne dermed ha blitt observert fra øya. Man kunne da valgt å avskjære med det eller de skip som hadde base ved Vardøhus, eller dersom fienden viste seg overlegen, trekke seg tilbake innenfor Vardøhus' murer sammen med lokalbefolkningen.

En slik hypotese forklarer plasseringen av det eldste Vardøhus ved Østvågen, et sted som ikke har vært best egnet i området ut fra et fortifikatorisk utgangspunkt, men som har gitt tilgang til en god havn. Å plassere anlegget på et høydedrag, enten på Vardøya eller på fastlandet, ville vært bedre både fra et fortifikatorisk utgangspunkt og med tanke på anleggets symbolvirkning. 
Når det gjelder Skansen i Tromsø, er den på lik linje med Vardøhus anlagt ved en god havn, men med en beliggenhet som fortifikatorisk ikke er spesielt fordelaktig. Skansen har riktignok ligget på et nes med sjø på tre sider, men også under et høydedrag. Fra Tromsøya har man ikke hatt muligheten til å kontrollere leia på samme måte som fra Vardøhus, siden en angriper ville hatt mulighet til å passere på utsiden av Kvaløya og dermed unngå Tromsøya. Vi må imidlertid ta med i betraktningen at Skansen mest sannsynlig ble anlagt på 1200-tallet, da det virker som konflikten dreide seg mer om retten til skattlegging av og handel med den samiske befolkningen, enn på 1300-tallet, da konflikten eskalerte til å bli en territoriell og politisk konflikt. Det er da grunn til å anta at sammenstøtene og angrepene på 1200-tallet i større grad kom over land og rammet bosetningene inne i fjordene. I lys av dette ligger Tromsøya strategisk gunstig til, med relativt kort avstand til alle de store fjordene fra Vest-Finnmark til Sør-Troms.

\title{
Avslutning
}

Fra 1100-tallet oppstod det en konkurranse om skattlegging og handel med den samiske befolkningen på Nordkalotten mellom Norge og Novgorods allierte karelere, som førte til væpnet konflikt. Samtidig ble inntektene fra eksportfisket i Nord-Norge så viktig for både kongemakten og kirken at begge ble pådrivere for en fiskeribasert bosetning eller kolonisering langs kysten av Troms og Finnmark. Med bakgrunn i konflikten med karelerne og som ledd i ekspansjonen nordøstover ser Skansen i Tromsø ut til å ha blitt anlagt på 1240-tallet av Håkon Håkonsson, muligens i kombinasjon med et kongelig kapell. Også Vardøhus, som vi kjenner fra kartmateriale fra slutten av 1500-tallet og utover, ser ut til å ha blitt anlagt på kongelig initiativ i første halvdel av 1300-tallet. Begge disse borgene hadde en symbolsk funksjon som markører for norsk overhøyhet i henholdsvis Troms og Finnmark, men har også vært anlagt ut fra militærstrategiske prinsipper, hvor tilgangen til havet har vært viktig. De kan meget godt ha fungert som baser for en leidangsflåte som til stadighet var operativ, slik borger ellers i Europa og i Midtøsten var baser for kavaleri og infanteri. Det er å håpe at fremtidige arkeologiske undersøkelser vil kunne legge grunnlag for en mer inngående forståelse av disse borgenes funksjon og betydning.

\author{
Note \\ 1 Gjengitt hos Nissen (1960).
}

\section{Summary \\ The medieval castles of Northern Norway}

While the medieval castles of Southern Norway were defensive fortifications on what traditionally was considered Norwegian territory, the castles of Northern Norway were frontier fortifications established on foreign territory. The northern part of what is today Troms County and Finnmark County were considered Sami territory before 1200. The Sami people traded with and were taxed by both the Novgorod-supported Karelians and the Norwegians. This led to hostilities between the Karelians and the Norwegians in the $13^{\text {th }}$ century. As part of the manifestation of Norwegian control over Troms County the castle Skansen was con- 
structed in the mid- $13^{\text {th }}$ century. This ancient looking earth and wood fortification was considered a strong enough defence against the Karelian enemy. During the $14^{\text {th }}$ century the income generated from the stockfish from the coast of Finnmark became increasingly important to the Norwegian King and Vardøhus further east in the County of Finnmark was constructed. Although still quite a weak fortification, this was a more modern castle constructed of stone. We know that in the Southern Norway naval leidang forces used castles as bases for attacks on Denmark in the $13^{\text {th }}$ century, and there is reason to believe that Skansen and Vardøhus were also bases for this medieval naval force.

\section{Litteratur}

Amundsen, Colin, Jørn Henriksen, Elin Myrvoll, Bjørnar Olsen og Przemyslaw Urbanczyk

2003 Crossing borders: Multi-room houses and inter-ethnic contacts in Europe's extreme north. Fennoscandia archaeologica 20:79-100.

Arntzen, Knut Ove

1971 Skansens historie. Ottar 68:5-19.

Bradbury, Jim

1992 The Medieval Siege. The Boydell Press, Woodbridge.

Bratrein, Håvard Dahl

1977 Russesagn i Nord-Norge. Ottar 94-95:5-12.

2002 Det eldste Vardøhus. Håløygminne 21:173-182.

Bruun, Inga Malene

2011 «De bor snart hist, snart her». Nordnorske fiskevær i middelalder. Ottar 286:54-61.

Christiansen, Eric

1997 The northern crusades. The Baltic and the Catholic frontier 1100-1525. Penguin Books, London.

DN: Diplomatarium Norvegicum. Oldbreve til Kundskab om Norges indre og ydre Forhold, Sprog, Sloegter, Sceder, Lovgivning og Rettergang i Middelalderen. Elektronisk dokument, http://www. dokpro.uio.no/dipl_norv/diplom_felt.html, besøkt 30. august 2018.

Ekroll, Øystein

2004 Norwegian Castles North of the Arctic Circle. I Castella Maris Baltici 6, redigert av Albinas Kuncevičius, s. 55-62. Savastis, Vilnius.

Eriksson, Anna-Lena

1995 Maktens boningar. Norska riksborgar under medeltiden. Lund Studies in Medieval Archaeology, vol. 14. Almqvist \& Wiksell, Stockholm.

Ersland, Geir Atle

2000 Kongshird og leidangsbonde. I Norsk forsvarshistorie, Bind 1, Krigsmakt og kongemakt 900-1814, del 1, redigert av Geir Atle Ersland og Terje H. Holm, s. 11-154. Eide forlag, Bergen.

Ersland, Geir Atle og Hilde Sandvik

1999 Norsk historie 1300-1625: eit rike tek form. Det Norske Samlaget, Oslo.

Fennoscandia

2016 Fennoscandia. Elektronisk dokument, https://commons.wikimedia.org/wiki/File:Fennoscandia. png, besøkt 30. august 2018.

Figenschow, Stefan

2011 Da korstogene kom til Tromsø...? Ottar 286:29-35.

Fischer, Gerhard

1951 Norske kongeborger. Gyldendal, Oslo.

Hagen, Rune Blix og Einar Sparboe

2004 Kongens reise til det ytterste nord. Ravnetrykk, vol. 33. Universitetsbiblioteket i Tromsø, Universitetet i Tromsø, Tromsø. 
Hansen, Lars Ivar og Bjørnar Olsen

2004 Samenes historie fram til 1750. Cappelen Akademisk Forlag, Oslo.

Harrison, Peter

2004 Castles of God. Fortified Religious Buildings of the World. The Boydell Press, Woodbridge.

Henriksen, Jørn

2016 Kulturmøte og identitet på Finnmarkskysten i tidlig historisk tid. Tolkninger basert på arkeologiske analyser av mangeromstufter. Upublisert doktorgradsavhandling, Universitetet $\mathrm{i}$ Tromsø, Tromsø.

Henriksen, Jørn, Camilla Nordby og Cora Oschman

2011 Artifacts: The Finds Retrieved. I Hybrid Spaces. Medieval Finnmark and the Archaeology of Multi-Room Houses, redigert av Bjørnar Olsen, Przemyslaw Urbañczyk og Colin Amundsen, s. 181-205. Novus Press, Oslo.

Härö, Elias

1981 Tavastehus Slott. Museiverket, Helsingfors.

Johnsen, Oscar Albert

1923 Finmarkens politiske historie: aktmoessig fremstillet. Skrifter utgitt av Det norske videnskapsakademi i Oslo II. Historisk-Filosofisk Klasse 1923(3). Dybwad, Kristiania.

Karlsson, Karl Henrik og Gustav Storm

1901 Finmarkens Beskrivelse af Erkebiskop Erik Walkendorf. Særtrykk av Det norske geografiske selskab 12, Kristiania.

Kaufmann Joseph Erich og Hanna Wanda Kaufmann

2004 The Medieval Fortress. Castles, Forts and Walled Cities of the Middle Ages. Da Capo Press, Boston.

Keegan, John

1994 A History of Warfare. Pimlico, London.

Keyser, Jakob Rudolf og Per Andreas Munch

1849 Norges gamle Love. Christian Gröndahl, Oslo.

Lie, Hallvard

1970 Egils saga. Aschehoug, Oslo.

Lind, Keth

2000 Den gamle borgen Skansen. I Tromsøboka: den andre, redigert av Pål Christensen, Sveinulf Hegstad, Ulf Jensen og Svein Smaaskjær, s. 36-47. Tromsøboka AS, Tromsø.

Lovén, Christian

1999 Borgar och befästningar i det medeltida Sverige. Kungl. Vitterhets historie och antikvitets akademiens handlingar, Antikvariska serien, vol. 40. Kungl. Vitterhets historie och antivitets akademien, Stockholm.

Michell, Robert og Nevill Forbes

1914 The chronicle of Novgorod 1016-1471. Offices of the Society, London.

Nicholson, Helen J.

2004 Medieval Warfare. Theory and Practice of War in Europe 300-1500. Palgrave Macmillan, Houndmills.

Nissen, Kristian

1960 Vardø og Vardøhus i eldre tid: hva gamle karter og dokumenter beretter. I Vardøhus festning 650 år. Jubileumsskrift, redigert av Gunnar Isaachsen Willoch, s. 19-65. Generalinspektøren for Kystvernartilleriet, Bokcentralen, Oslo.

Nordeide, Sæbjørg Walaker

2000 Steinvikholm slott - på overgangen fra middelalder til nyere tid. NIKU Temahefte 23. Norsk institutt for kulturminneforskning, Trondheim.

Nossov, Konstantin

2007 Medieval Russian Fortresses AD 862-1480. Osprey Publishing, Oxford. 
RN: Regesta Norvegica. Kronologisk Fortegnelse over Dokumenter vedkommende Norge, Nordmand og den norske Kirkeprovins. Norsk historisk kjeldeskrift-institutt. Elektronisk dokument, http://

Robberstad, Knut www.dokpro.uio.no/dipl_norv/regesta_felt.html, besøkt 30. august 2018.

1937 Gulatingslovi. Samlaget, Oslo.

Sagvolden, André Wallin

2003 Korstogene til Øst-Baltikum tidlig i det 13. århundre. Middelalderforum 3(1-2):183-208.

Simonsen, Povl

1959 Jordfunn fra Vardø. Vardøhus Museum Arbok 1959:8-56.

Sinding-Larsen, Holger

1937 Vardøen. De forskjellige befestningsanlegg frem gjennem tidene. Det Norske videnskapsakademi i Oslo II, Historisk-Filosofisk Klasse 1937(1). Dybwad, Oslo.

Stangeland, Gro og Eva Valebrokk

2001 Norges bedste Veern og Faeste. Nasjonale festningsverk. Wigestrand Forlag, Stavanger.

Storm, Gustav

1888 Islandske Annaler indtil 1578. Det Norske historiske Kildeskriftfonds skrifter, vol. 21. Grøndahl, Christiania.

Sturlason, Snorre

1984 Snorres kongesagaer, bind 2. Oversatt av Hanne Holtsmark og Didrik Arup Seip. Gyldendal, Oslo.

Sundberg, Ulf

1999 Medeltidens svenska krig. Hjalmarson \& Högberg, Stockholm.

Svenungsen, Pål Berg

2016 Norge og korstogene. En studie av forbindelsene mellom det norske riket og den europeiske korstogsbevegelsen, ca. 1050-1380. Upublisert doktorgradsavhandling, Universitetet i Bergen, Bergen.

Tordsson, Sturla

1979 [1265] Norges kongesagaer, bind 4. Oversatt av Finn Hødnebø. Gyldendal, Oslo.

Trædal, Vidar

2008 Kirkesteder og kirkebygninger i Troms og Finnmark før 1800. Upublisert doktorgradsavhandling, Universitetet i Tromsø, Tromsø.

Turnbull, Stephen

2004 Crusader Castles of the Teutonic Knights (2). The stone castles of Latvia and Estonia 1185-1560. Osprey Publishing Ltd, Oxford.

Tveit, Miriam

2015 Integrasjon gjennom lovgivning? Rettsresepsjon I Hålogaland 1100-1500. Heimen 52:134-147.

Urban, William

1975 The Baltic crusade. Northern Illinois University Press, DeKalb.

Urbanczyk, Przemyslaw

1992 Medieval Arctic Norway. Semper, Warszawa.

Wallerström, Thomas

1995 Norrbotten, Sverige och medeltiden. Problem kring makt och bosättning $i$ en europeisk periferi. Almqvist \& Wiksell, Stockholm.

Willoch, Gunnar Isaachsen

1960a Jordfunne kanondeler fra Vardøhus. I Vardøhus festning 650 år. Jubileumsskrift, redigert av Gunnar Isaachsen Willoch, s. 167-182. Generalinspektøren for Kystvernartilleriet, Bokcentralen, Oslo.

1960b Vardøhus slott. I Vardøhus festning 650 år. Jubileumsskrift, redigert av Gunnar Isaachsen Willoch, s. 66-71. Generalinspektøren for Kystvernartilleriet, Bokcentralen, Oslo. 